\title{
Hydrogen sulfide removal from biogas using a salak fruit seeds packed bed reactor with sulfur oxidizing bacteria as biofilm
}

\author{
Retno A.S. Lestari ${ }^{\mathrm{a}, \mathrm{b}, *}$, Wahyudi B. Sediawan ${ }^{\mathrm{a}}$, Siti Syamsiah ${ }^{\mathrm{a}}$, Sarto ${ }^{\mathrm{a}}$, \\ Jose Antonio Teixeira ${ }^{c}$ \\ a Chemical Engineering Department, Gadjah Mada University, Yogyakarta, Indonesia \\ ${ }^{\mathrm{b}}$ Chemical Engineering Department, 17 Agustus 1945 University, Semarang, Indonesia \\ c Department of Biotechnology Engineering, University of Minho, Braga, Portugal
}

\section{A R T I C L E I N F O}

\section{Article history:}

Received 29 December 2015

Received in revised form 8 April 2016

Accepted 9 April 2016

Available online 14 April 2016

\section{Keywords:}

Biofilm

Biogas

Packed bed reactor

Salak fruit seeds

Sulfur-oxidizing bacteria

\section{A B S T R A C T}

A packed bed reactor was evaluated for hydrogen sulfide $\left(\mathrm{H}_{2} \mathrm{~S}\right)$ removal by sulfur-oxidizing bacteria attached as a biofilm on salak fruit seeds (SFS). The bacteria were isolated from the sludge of the wastewater of a biogas plant. The promising isolate from the previous work was used in a biofilter, and its capacity to remove $\mathrm{H}_{2} \mathrm{~S}$ was evaluated at effects of time of operation, effects of biogas flow rate, effects of axial distance, and packing material. Obtained results showed that isolate attached to SFS in an $80 \mathrm{~cm}$ height and $8 \mathrm{~cm}$ inside diameter biofilter column could decrease $\mathrm{H}_{2} \mathrm{~S}$ in biogas from $142.48 \mathrm{ppm}$ to $4.06 \mathrm{ppm}$ (97.15\% removal efficiency) for a biogas flow rate of $8550 \mathrm{~g} \mathrm{~m}^{-3} \mathrm{~h}^{-1}$ corresponding to a residence time of $4 \mathrm{~h}$.

Simple kinetic models of sulfide removal and bacterial growth was proposed to describe the operation of the biofilter. The radial $\mathrm{H}_{2} \mathrm{~S}$ concentration gradient in the flowing gas is to be neglected so is the $\mathrm{H}_{2} \mathrm{~S}$ concentration in the biofilm at certain axial distance. Meanwhile, the rate of $\mathrm{H}_{2} \mathrm{~S}$ degradation was approximated by Monod type equation.

The obtained simultaneous ordinary differential equations solved by Runge-Kutta method. Comparing the calculated results and the experimental data, it can be concluded that model proposed can sufficiently describe the performance of the $\mathrm{H}_{2} \mathrm{~S}$ removal. The suitable values of the parameters are as follows: $\mu_{\max }=0.0000007\left(\mathrm{~s}^{-1}\right), \mathrm{K}_{\mathrm{S}}=0.0000039\left(\mathrm{~g} \mathrm{~cm}^{-3}\right), \mathrm{k}_{\mathrm{G}}=0.0086\left(\mathrm{~cm} \mathrm{~s}^{-1}\right), \mathrm{H}_{\mathrm{S}}=0.9\left(\left(\mathrm{~g} \mathrm{~cm}^{-3}\right) /\right.$ $\left.\left(\mathrm{g} \mathrm{cm}^{-3}\right)\right)$, and $\mathrm{Y}_{\mathrm{x} / \mathrm{s}}=10$.

(c) 2016 Elsevier Ltd. All rights reserved.

\section{Introduction}

Biogas is the product of the anaerobic digestion process of biological materials, in which organic matter such as animal wastes, household wastes, crop residues, sewage sludge, wastewater, and landfill [1] is degraded by anaerobic bacteria, according to the following steps: hydrolysis, acidogenesis, acetogenesis and methane fermentation [2]. Raw biogas consists mainly of methane, carbon dioxide, and a small amount of various residual compounds such as water vapor, hydrogen sulfide, ammonia, siloxanes, and mercaptans [3].The composition of produced biogas is $55-70 \%$ $\mathrm{CH}_{4}, 30-45 \mathrm{CO}_{2}$, and $0-1.5 \% \mathrm{H}_{2} \mathrm{~S}$ [4]. Hydrogen sulfide in biogas is originated from the degradation of proteins and the sulfur

\footnotetext{
Abbreviations: SFS, salak fruit seed; SOB, sulfur oxidizing bacteria.

* Corresponding author.

E-mail address: retnotengaran@gmail.com (R.A.S. Lestari).
}

compounds in the feed [4]. Although the concentration of $\mathrm{H}_{2} \mathrm{~S}$ in the biogas depends on the feedstock, it is usually varies between $0.1-2 \%$ [5]. Hydrogen sulfide is highly toxic, corrosive [6], colorless and responsible for the foul odor of rotten eggs [7]. Furthermore, $\mathrm{H}_{2} \mathrm{~S}$ is one of the major problems in biogas utilization as in the range $50-10,000 \mathrm{ppm}$, it could cause corrosion in the engines and pipelines especially when used as fuel for producing electricity [8].

Several physicochemical processes have been used to remove $\mathrm{H}_{2} \mathrm{~S}$ from industrial waste gas streams which include absorption $[9,10]$, scrubbing [11], and adsorption [12] processes. Meanwhile, biofiltration is an alternative process for $\mathrm{H}_{2} \mathrm{~S}$ removal from gas $[7,13]$.

There are two types of absorption methods. The first one is absorption by water which needs a lot of water [11], requires high pressure, works effectively for low gas flow rates only and produces other types of waste. The second method is absorption using water containing chemicals $[9,10]$, which produces chemical wastes as well as needs high cost chemicals [14]. Meanwhile, 


\begin{tabular}{|ll|}
\hline Nomenclature \\
$S$ & Surface area of biofilm $\left(\mathrm{cm}^{2}\right)$ \\
$a_{S}$ & Surface area of biofilm to bed volume $\left(\mathrm{cm}^{2} / \mathrm{cm}^{3}\right)$ \\
$C_{g}$ & Sulfide concentration in gas $\left(\mathrm{g} / \mathrm{cm}^{3}\right)$ \\
$C_{g i}$ & Sulfide concentration in gas film interface $(\mathrm{g} / \mathrm{cm} 3)$ \\
$C_{S i}$ & Sulfide concentration in biofilm interface $(\mathrm{g} / \mathrm{cm} 3)$ \\
$C_{S}$ & Sulfide concentration in biofilm $(\mathrm{g} / \mathrm{cm} 3)$ \\
$H_{S}$ & Henry's constant \\
$r_{x}$ & Rate of bacterial growth \\
$K_{S}$ & Monod's constant \\
$\mathrm{Y}_{\mathrm{x} / \mathrm{s}}$ & Mass of microorganisms growth to mass of sulfide \\
& consumed \\
$\mathrm{Greek}$ & Symbols \\
$\alpha$ & Saturation constant $(\mathrm{g} / \mathrm{m} 3)$ \\
$\delta$ & Thickness of biofilm $(\mathrm{m})$ \\
$\varepsilon$ & Porosity \\
$\rho$ & Mass of microorganisms pervolume of biofilm $(\mathrm{g} / \mathrm{m} 3)$ \\
$\mu_{\mathrm{max}}$ & Rate of maximum spesific growth $(1 /$ day) \\
\hline
\end{tabular}

adsorption methods need high cost adsorbent, high pressure, a regeneration step and also work effectively for low gas flow rate only [14]. On the other hand, biofiltration needs low investment and operating costs, operates at low pressure-drop, does not produces further waste and works effectively for $\mathrm{H}_{2} \mathrm{~S}$ removal at low concentration at high flow rate [15]. Despite of some drawbacks of biofiltration, such as relatively slow and sensitive to operating conditions and contamination [15], it is still used for the aforementioned reasons.

Biofiltration is a multi-phase system in which contaminated gas is dissolved and absorbed in the biofilm, and then degraded by microorganisms that are immobilized on a packing material forming a thin layer (biofilm). [15]. The packing material in the biofilter may be both natural and synthetic and must fulfill the requirements of high surface area, high permeability, and high adsorbance. Previous research work used soil, compost, wood chips, leaves, tree bark, sawdust, sand, and bagasse $[15,16]$. The support matrix for the microorganisms or packing material is an important factor in the design of a biofiltration unit. The packing material must have a high porosity as well as high water retention capacity. The nutrient presence and availability are also important [17]. Organic materials have both the presence of nutrients and higher water holding capacity than inorganic packing materials. Most biofilter media commonly applied are peat and compost with inert bulking agents such as activated carbon, wood chips or beads [18]. Composts are frequently used as they allow for a denser and more varied microbial population as well as good water holding capacity and nutrients retention. However, composts have low porosity, so the pressure drop in the biofilter will be high. Soils are prone to short circuiting and clogging [14]. Activated carbon has better properties concerning surface area, homogeneity and hardness, thus offering a better performance. While disadvantage of activated carbon is in higher price compare to other natural source for the reason that activated carbon need special treatment in a manufacturing process [19].

Grains are a possible option for a biomedia to be used as packing, due to its fibrous structure that facilitates water and gas flow with low pressure-drop [16]. Salak fruit seeds (SFS) are agricultural waste dificult to be degraded and utilized. Salak fruit (Salacca zalacca) is angiospermae plant or plant with a closed seed. These plants are characterized by having a rigid structure on their wall cell, containing cellulose. Cellulose is a long fiber which combines with hemicelluloses, pectin and protein to form the cell wall of the plant. Cellulose has a significant potential to be used as packing in a biofilter [20]. SFS has a hard texture, dark brown color and the shape is elliptical with a linear dimension of $1-2 \mathrm{~cm}$. Salak fruit seeds are organic material of high porosity with low bulk density. The utilization of SFS as biomedia in a biofilter to eliminate $\mathrm{H}_{2} \mathrm{~S}$ gas from biogas is a new option, as no previous research was done with this kind of packing.

Pure or mixed culture bacteria can be applied to the packing of the biofilter. A pure culture can be acquired from a culture collection or prepared by isolating a bacteria from a mixed culture, obtained from a sludge. The use of a mixed culture to remove $\mathrm{H}_{2} \mathrm{~S}$ has been shown to be more efficient and stable on the long term operation compared to the use of species that come from an isolation process [19]. There are several microorganisms that could be utilized in sulfur removal. Lee et al. [21], studied the chemoautotroph bacteria Acidithiobacillus thiooxidans or formerly Thiobacillus thioxidans. From the same group, Fischer et al. [18] utilized Acidithiobacillus ferrooxidans also known as Thiobacillus feroxidans. Edmonds et al. [22] utilized Chromatiaceae (Chlorobioceae) a photoautotroph bacteria.

In this study, the use of biofilm attached on SFS for $\mathrm{H}_{2} \mathrm{~S}$ removal was explored. The performance was evaluated by observing the $\mathrm{H}_{2} \mathrm{~S}$ concentration in the gas at various position and time. The process of removal was quantitatively discribed by kinetics modelling. The accuracy of the models were tested by comparing the calculated results and the experimental data. The values of the parameters involved were obtained by curve fitting.

\section{Materials and methods}

\subsection{Material}

Salak fruit seeds (SFS) used as a packing material were harvested from Sleman, Yogyakarta, Indonesia. The material was prepared as described in Lestari et al. [23]. The SFS were washed and then dried in an oven at $55^{\circ} \mathrm{C}$ to eliminate all volatile impurities and the water. Drying operation was carried in $55^{\circ} \mathrm{C}$ to avoid SFS cracking. Dried SFS contains $0.09 \%$ sulfur (S), $11.408 \%$ carbon $(\mathrm{C})$ and $0.064 \%$ total nitrogen $(\mathrm{N})$. Other results of SFS analysis are as follows: $19.40 \%$ water content, $\mathrm{pH}$ of 6.89 , and porosity of 0.55 .

The bacteria used in this research is isolate 12 that obtained from previous research by Lestari et al. [23]. It was isolated from the sludge of the wastewater of a biogas plant available at a tofu processing industry in Srandakan, Bantul Yogyakarta, Indonesia. The obtained isolates were screened for their efficiency in $\mathrm{H}_{2} \mathrm{~S}$ removal and the most efficient immobilized on the surface of SFS in a biofilter. Laboratory analysis showed that the promising isolate (isolate 12) belongs to the Thiobacillus group.

For the growth of the sulfur oxidizing bacteria (SOB), a medium consisting of $0.4 \mathrm{~g} / \mathrm{l} \mathrm{NH} \mathrm{Cl}_{4} \mathrm{Cl}, 0.2 \mathrm{~g} \mathrm{~L}^{-1} \mathrm{MgCl} \cdot 6 \mathrm{H}_{2} \mathrm{O}, 0.2 \mathrm{~g} \mathrm{~L}^{-1} \mathrm{KH}_{2} \mathrm{PO}_{4}$, $0.2 \mathrm{~g} \mathrm{~L}^{-1} \mathrm{~K}_{2} \mathrm{HPO}_{4}, 0.2 \mathrm{~g} \mathrm{~L}^{-1}$ yeast extract and $8 \mathrm{~g} \mathrm{~L}^{-1} \mathrm{Na}_{2} \mathrm{~S}_{2} \mathrm{O}_{3} \cdot 5 \mathrm{H}_{2} \mathrm{O}$ was used [21]. Medium and equipment were sterilized in an autoclave at $121^{\circ} \mathrm{C}, 1.2 \mathrm{~atm}$ for $15 \mathrm{~min}$.

Biogas was collected from Integrated Farming Unit, Agricultural Research and Development for Education (KP4) Facility, Gadjah Mada University. The biogas contains $10 \mathrm{ppm}$ up to $200 \mathrm{ppm}$ of $\mathrm{H}_{2} \mathrm{~S}$.

\subsection{Methods}

\subsubsection{Biofilter experiments}

Immobilatization of isolate 12 on SFS is as follows, approximately $2.5 \mathrm{~kg}$ of dried SFS and $3000 \mathrm{~mL}$ of SOB medium was mixed in a flask and sterilized at $121^{\circ} \mathrm{C}$ and $1.2 \mathrm{~atm}$ for $15 \mathrm{~min}$. The 
sterilized-mixture was then mixed with $300 \mathrm{~mL}$ of isolate 12 and kept at $30^{\circ} \mathrm{C}$ at atmospheric pressure for six days to let the biofilm grow on SFS surface. The SFS covered by biofilm was then used as packing material in the packed bed reactor. Prior to the continuous experiments, SOB medium was added to the biofilter to feed the microorganisms in the beginning of process. The column for the biofilter reactor was made of acrilic resin which has an inside diameter of $8.0 \mathrm{~cm}$ and a height of $100 \mathrm{~cm}$. The height of SFS packing was $80 \mathrm{~cm}$.

Biogas was fed continuously to the bottom side of the column under specified flow rate (Fig. 1). At every 2 h, biogas samples were taken through the sample ports following the standard procedure of Indonesia National Standard (SNI) 19.7117.7-2005, in which the biogas samples from the column were dissolved in a bottle filled with water containing $\mathrm{ZnSO}_{4}, \mathrm{NaOH}$, and $\left(\mathrm{NH}_{4}\right)_{2} \mathrm{SO}_{4}$.

\subsubsection{Model development}

In order to get better understanding of the phenomena and to generalize the results obtained, a kinetics studies supported by mathematical modelling were conducted. The kinetics models applied in this study are essentially similar to the ones proposed by Lestari et al. [24]. In this paper, the main considerations for the development of the model are described in detail. In this process, the biofilm is attached to the packing material and the $\mathrm{H}_{2} \mathrm{~S}$ containing biogas is fed to the column. The $\mathrm{H}_{2} \mathrm{~S}$ in the gas is converted to a non-hazardous sulfur compound by the bacteria in the biofilm and stored in the microbial cells. Kinetics models to quantitatively describe the process are proposed. The models were developed based on the following assumptions:

1. The gas flow through the bed inside the column at various radial positions is uniform (plug flow).

2. The $\mathrm{H}_{2} \mathrm{~S}$ concentration in the bulk flow of the gas is uniform.

3. The column is isothermal.

The mechanism of the process is then proposed as follows (Fig. 1):

a The $\mathrm{H}_{2} \mathrm{~S}$ from the bulk of gas is transfered to the surface of the biofilm through a gas film. The rate of $\mathrm{H}_{2} \mathrm{~S}$ mass transfer is similar to the one of absorption. The rate of mass transfer through the gas film can be approximated by Eq. (1) [25]:

$$
N_{A}=k_{g}\left(C_{g}-C_{g i}\right)
$$

b The $\mathrm{H}_{2} \mathrm{~S}$ then diffuses into the inner part of the biofilm.

c While diffusing through the biofilm, part of the $\mathrm{H}_{2} \mathrm{~S}$ is converted by the bacteria in the biofilm. The rate of the sulfur consumption by bacteria is approximated by Monod's

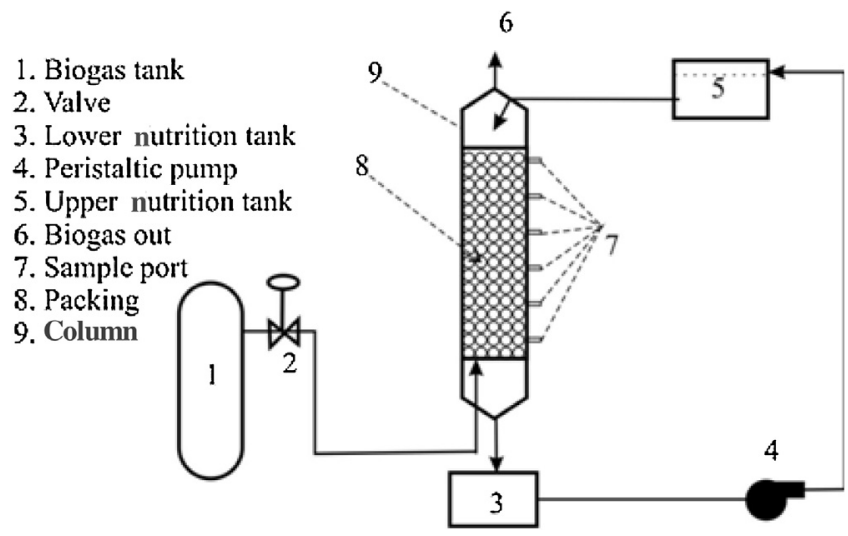

Fig. 1. Experimental equipment. equation as follows [26]:

$$
r_{A}=\frac{\mu_{\max } C_{S}}{C_{S}+K_{S}}
$$

4. The product of the $\mathrm{H}_{2} \mathrm{~S}$ conversion is a non-hazardous sulfur compound stored in the cell of bacteria.

5. By consuming $\mathrm{H}_{2} \mathrm{~S}$ compounds, the bacteria grows. The growth rate is assumed to be proportional to the amount of the $\mathrm{H}_{2} \mathrm{~S}$ compounds consumed. Hence, the thickness of the biofilm increases

The detailed diagram of the $\mathrm{H}_{2} \mathrm{~S}$ mass transfer around the biofilm is shown in Fig. 2.

The profile of the $\mathrm{H}_{2} \mathrm{~S}$ concentration around the biofilm is as presented in Fig. 3, considering the following assumptions:

1. Hydrogen sulfide concentration in the biofilter for a given height is considered to be uniform $\left(C_{s}\right)$ This simplification is based on the consideration that the diffusion through the biofilm is relatively fast, since the biofilm thickness $(\delta)$ is relatively small.

2. The microorganisms concentration in the bio-film at the same axial position in the bed is also assumed to be uniform.

Combination of mass balance of $\mathrm{H}_{2} \mathrm{~S}$ in the biogas stream in the bed of thickness $\Delta z$ (Fig. 4) and application of Eq. (1) gives:

$\left[\begin{array}{c}\text { Rate of } \\ \text { Input }\end{array}\right]-\left[\begin{array}{c}\text { Rate of } \\ \text { Output }\end{array}\right]-\left[\begin{array}{c}\text { Rate of } \\ \text { Reaction }\end{array}\right]=\left[\begin{array}{c}\text { Rate of } \\ \text { Accumulation }\end{array}\right]$

$\frac{\left.G \cdot C_{g}\right|_{Z+\Delta Z}-\left.G \cdot C_{g}\right|_{Z}}{\Delta Z}+k_{g}\left(C_{g}-C_{g i}\right) a_{S} S=S \varepsilon \frac{\partial C_{g}}{\partial t}$

If limit $\Delta z \rightarrow 0$ :

$G \frac{\partial C_{g}}{\partial z}+k_{g}\left(C_{g}-C_{g i}\right) a_{s} S=-S \varepsilon \frac{\partial C_{g}}{\partial t}$

For pseudo steady-state process in the gas phase, $\partial C_{g} / \partial t=0$, so Eq. (5) becomes:

$0=\frac{G d C_{g}}{\varepsilon S d z}+\frac{k_{g} a_{S}}{\varepsilon}\left(C_{g}-C_{g i}\right)$

$\frac{d C_{g}}{d z}=-\frac{k_{g} a_{S} S}{G}\left(C_{g}-C_{g i}\right)$

The mass balance of $\mathrm{H}_{2} \mathrm{~S}$ in the bio-film at certain $\mathrm{z}$ position (Fig. 4) and the application of Eq. (1) results in:

$\left[\begin{array}{c}\text { Rate of } \\ \text { Input }\end{array}\right]-\left[\begin{array}{c}\text { Rate of } \\ \text { Output }\end{array}\right]-\left[\begin{array}{c}\text { Rate of } \\ \text { Reaction }\end{array}\right]=\left[\begin{array}{c}\text { Rate of } \\ \text { Accumulation }\end{array}\right]$

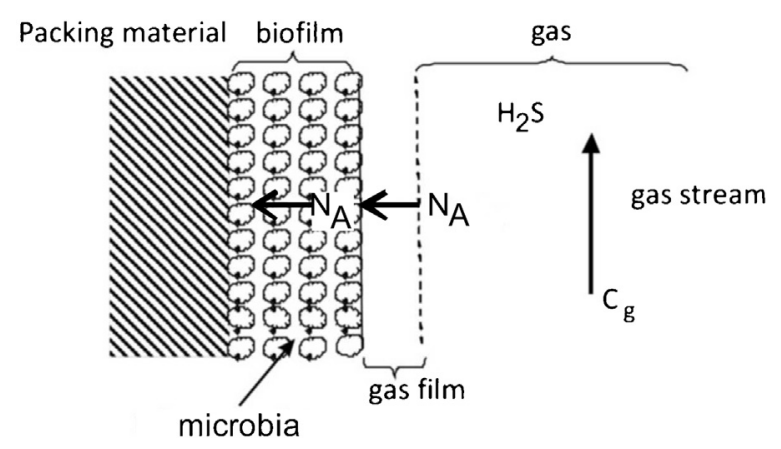

Fig. 2. Hydrogen sulfide mass transfer around biofilm. 


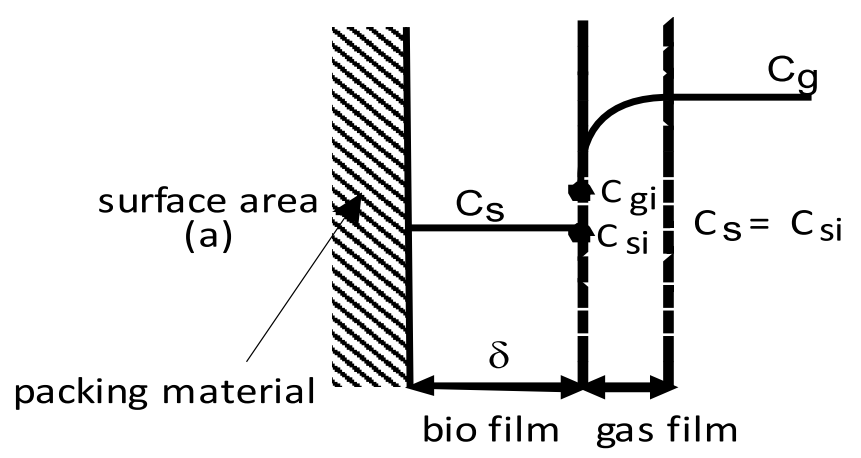

Fig. 3. Profile of $\mathrm{H}_{2} \mathrm{~S}$ concentration.

$k_{g} a\left(C_{g}-C_{g i}\right)-0-a \times \delta \times r_{A}=\frac{d C_{S}}{d t}$

$\frac{d C_{S}}{d t}=\frac{k_{g}}{\delta}\left(C_{g}-C_{g i}\right)-r_{A}$

In Eq. (10) $\mathrm{C}_{\mathrm{gi}}$ is the concentration of $\mathrm{H}_{2} \mathrm{~S}$ in the gas phase that is in equilibrium with $\mathrm{H}_{2} \mathrm{~S}$ concentration in the surface of biofilm $\left(\mathrm{C}_{\mathrm{Si}}\right)$. According to distribution concept [25]:

$C_{g i}=H_{S} C_{S i}$

Based on assumption number 1 shown in Fig. 3, the value of $\mathrm{C}_{\mathrm{Si}}$ is equal to $C_{S}$, so Eq. (11) becomes:

$C_{g i}=H_{S} C_{S}$

Since the rate of bacterial growth is proportional to the rate of $\mathrm{H}_{2} \mathrm{~S}$ consumption (Eq. (2)), the rate of the bacterial growth can be approximated by:

$r_{X}=Y_{x / s} \times r_{A}=Y_{x / s} \frac{\mu_{\max } C_{S}}{C_{S}+K_{S}}$

Since the biofilm thickness at a certain time is $\delta$, the rate of increase of the mass of microorganisms is:

$\frac{\mathrm{dm}}{\mathrm{dt}}=\mathrm{r}_{\mathrm{X}} \mathrm{a} \delta$

where $Y_{x / s}$ is the yield coefficient in terms of the ratio of the mass of microorganisms growth to the mass of $\mathrm{H}_{2} \mathrm{~S}$ consumed. Since the mass of microorganisms $m=\rho \mathrm{V}$, where $\rho$ is mass of microorganisms per volume of biofilm and $\mathrm{V}$ is the volume of biofilm,

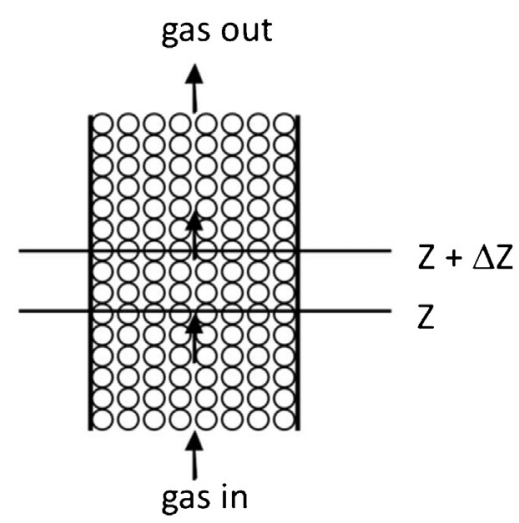

Fig. 4. Schematic diagram of the volume element in the packed bed system.
Eq. (14) becomes:

$\frac{\mathrm{d}(\rho \times \mathrm{a} \times \delta)}{\mathrm{dt}}=\mathrm{Y}_{\mathrm{x} / \mathrm{s}} \mathrm{r}_{\mathrm{A}} \mathrm{a} \delta$

Since the surface area of the biofilm (a) is relatively constant, Eq. (15) can be simplified as follows:

$\frac{\mathrm{d} \delta}{\mathrm{dt}}=\frac{\mathrm{Y}_{\mathrm{x} / \mathrm{s}}}{\rho} \mathrm{r}_{\mathrm{A}} \delta$

Thus, the mathematical models representing the $\mathrm{H}_{2} \mathrm{~S}$ removal from biogas using biofilm on packed bed of SFS are the set of Eqs. (2),(7), (10), (12) and (16). The proposed models have been tested for the experimental data obtained by Fischer [18] and give reasonably results [24]. Accuracy of the models will further be verified with the data obtained from the experiment.

\section{Results and discussion}

\subsection{Hydrogen sulfide removal in the biofilter}

In order to explore the process of $\mathrm{H}_{2} \mathrm{~S}$ removal in the packed bed, the experimental data correlating the $\mathrm{H}_{2} \mathrm{~S}$ concentration at various axial positions in the column and times of operation were shown in Table 1. Since the $\mathrm{H}_{2} \mathrm{~S}$ concentration in the feed at each run was not constant, to make the comparison easier, the percentage of $\mathrm{H}_{2} \mathrm{~S}$ recovery at various positions and times of operation were also shown. The percentage of $\mathrm{H}_{2} \mathrm{~S}$ removal efficiency was defined as the decrease of $\mathrm{H}_{2} \mathrm{~S}$ concentration devided by the $\mathrm{H}_{2} \mathrm{~S}$ concentration in the biogas feed.

\subsubsection{Effects of time of operation}

From Table 1, a set of data was taken and shown in Fig. 5 as an example of correlation between removal efficiency and hydrogen sulfide concentration to the distance of SFS bed from the biogas inlet in a various time of operation.

Data in Fig. 5 show that the $\mathrm{H}_{2} \mathrm{~S}$ removal efficiency increase with increasing time of operation, for different initial concentration of $\mathrm{H}_{2} \mathrm{~S}$ in biogas. This is conceivable since the biofilm grows on SFS surface troughout the column and a larger biofilm mass will consume more $\mathrm{H}_{2} \mathrm{~S}$, resulting in the higher $\mathrm{H}_{2} \mathrm{~S}$ removal. This microbia growth can be visually observed by the increase of the thickness of biofilm formed on the surface of the SFS. As shown in Table 1 , in the flow rate of $30 \mathrm{~L} \mathrm{~h}^{-1}\left(8550 \mathrm{~g} \mathrm{~m}^{-3} \mathrm{~h}^{-1}\right), \mathrm{H}_{2} \mathrm{~S}$ removal efficiency at the outlet of packing system $(80 \mathrm{~cm}$ from the gas inlet) was $67 \%, 76 \%$ and $97 \%$ following time of operation of $0 \mathrm{~h}, 2 \mathrm{~h}$ and $4 \mathrm{~h}$, respectively. Similar trend was also found for the other gas flow rates. This is consistent with the data of Wani et al. [27] in the removal of $\mathrm{H}_{2} \mathrm{~S}$ using biofilters containing compost, hog fuel and mixture of compost and hog fuel in a packed bed system. In their studies, at the time of $5 \mathrm{~h}$, removal efficiency reached $10 \%$ for the mixture packed bed, $13 \%$ for the compost packed bed, and $15.5 \%$ for hog fuel packed bed, while at $20 \mathrm{~h}$ the removal efficiency reached $16.5 \%$ for the mixture, $19 \%$ for the compost and $18.5 \%$ for the hog fuel. At $30 \mathrm{~h}$, removal efficiency reached $18.5 \%$ for the mixture, $20 \%$ for the compost and 19.5\% for the hog fuel. This comparison shows that the experimental data obtained were consistent with the ones of other researchers.

\subsubsection{Effects of biogas flow rate}

Table 1 presented the data for biogas flowrate between $30 \mathrm{~L} \mathrm{~h}^{-1}$ to $84 \mathrm{Lh}^{-1}\left(8550 \mathrm{~g} \mathrm{~m}^{-3} \mathrm{~h}^{-1}\right.$ to $\left.23940 \mathrm{~g} \mathrm{~m}^{-3} \mathrm{~h}^{-1}\right)$. After $4 \mathrm{~h}$ of operation, correlation between the distances of SFS bed from the biogas inlet at a various biogas flowrate was shown in Fig. 6.

As shown in Fig. 6, the $\mathrm{H}_{2} \mathrm{~S}$ removal efficiency in a different position from the gas inlet indicates that the lower gas flowrate results in higher removal efficiency. This fact may be described as 
Table 1

Hydrogen sulfide concentration in biogas at various time and flow rate.

\begin{tabular}{|c|c|c|c|c|c|}
\hline Flow rates $\left(\mathrm{Lh}^{-1}\right)$ & Flow rate $\left(\mathrm{g} \mathrm{m}^{-3} \mathrm{~h}^{-1}\right)$ & $\begin{array}{l}\text { Time } \\
\text { (h) }\end{array}$ & Distance to bottom of packing & $\mathrm{H}_{2} \mathrm{~S}$ Concentration (ppm) & $\begin{array}{l}\mathrm{H}_{2} \mathrm{~S} \text { Removal } \\
\text { Efficiency (\%) }\end{array}$ \\
\hline \multirow[t]{15}{*}{30} & 8550 & 0 & 0 & 179.62 & 0.00 \\
\hline & & & 20 & 163.90 & 8.75 \\
\hline & & & 40 & 119.67 & 33.38 \\
\hline & & & 60 & 98.24 & 45.31 \\
\hline & & & 80 & 59.00 & 67.15 \\
\hline & & 2 & 0 & 163.90 & 0.00 \\
\hline & & & 20 & 138.22 & 15.67 \\
\hline & & & 40 & 96.26 & 41.27 \\
\hline & & & 60 & 39.11 & 76.14 \\
\hline & & & 80 & 23.44 & 85.70 \\
\hline & & 4 & 0 & 142.48 & 0.00 \\
\hline & & & 20 & 104.40 & 26.73 \\
\hline & & & 40 & 49.00 & 65.61 \\
\hline & & & 60 & 24.15 & 83.05 \\
\hline & & & 80 & 4.06 & 97.15 \\
\hline \multirow[t]{15}{*}{48} & 13680 & 0 & 0 & 87.85 & 0.00 \\
\hline & & & 20 & 82.69 & 5.87 \\
\hline & & & 40 & 75.60 & 13.94 \\
\hline & & & 60 & 53.01 & 39.66 \\
\hline & & & 80 & 41.49 & 52.77 \\
\hline & & 2 & 0 & 89.99 & 0.00 \\
\hline & & & 20 & 73.31 & 18.54 \\
\hline & & & 40 & 56.96 & 36.70 \\
\hline & & & 60 & 37.89 & 57.90 \\
\hline & & & 80 & 15.49 & 82.79 \\
\hline & & 4 & 0 & 89.51 & 0.00 \\
\hline & & & 20 & 60.98 & 31.87 \\
\hline & & & 40 & 45.92 & 48.70 \\
\hline & & & 60 & 22.17 & 75.23 \\
\hline & & & 80 & 5.06 & 94.35 \\
\hline \multirow[t]{15}{*}{66} & 18810 & 0 & 0 & 10.97 & 0.00 \\
\hline & & & 20 & 8.90 & 18.87 \\
\hline & & & 40 & 6.78 & 38.20 \\
\hline & & & 60 & 4.59 & 58.16 \\
\hline & & & 80 & 1.71 & 84.41 \\
\hline & & 2 & 0 & 25.03 & 0.00 \\
\hline & & & 20 & 20.04 & 19.94 \\
\hline & & & 40 & 13.71 & 45.23 \\
\hline & & & 60 & 10.05 & 59.85 \\
\hline & & & 80 & 1.94 & 92.25 \\
\hline & & 4 & 0 & 41.44 & 0.00 \\
\hline & & & 20 & 39.56 & 4.54 \\
\hline & & & 40 & 30.53 & 26.33 \\
\hline & & & 60 & 21.78 & 47.44 \\
\hline & & & 80 & 2.50 & 93.97 \\
\hline \multirow[t]{15}{*}{84} & 23940 & 0 & 0 & 144.55 & 0.00 \\
\hline & & & 20 & 130.68 & 9.60 \\
\hline & & & 40 & 127.84 & 11.56 \\
\hline & & & 60 & 111.74 & 22.70 \\
\hline & & & 80 & 100.00 & 30.82 \\
\hline & & 2 & 0 & 149.13 & 0.00 \\
\hline & & & 20 & 122.30 & 17.99 \\
\hline & & & 40 & 110.00 & 26.24 \\
\hline & & & 60 & 86.00 & 42.33 \\
\hline & & & 80 & 68.70 & 53.93 \\
\hline & & 4 & 0 & 118.17 & 0.00 \\
\hline & & & 20 & 105.82 & 10.45 \\
\hline & & & 40 & 85.76 & 27.43 \\
\hline & & & 60 & 54.27 & 54.07 \\
\hline & & & 80 & 29.11 & 75.40 \\
\hline
\end{tabular}

the following. As the gas flowrate is increased, the contact time between $\mathrm{H}_{2} \mathrm{~S}$ and microorganism on SFS is shorter, thus only a smaller part of the $\mathrm{H}_{2} \mathrm{~S}$ could be degraded by the microorganism. This observation is consistent with the study by Dumont and Andrès [28] which found that by utilizing peat-UP20 (mixed) as packing material, $\mathrm{H}_{2} \mathrm{~S}$ removal efficiency could reach $100 \%$ at the flow rates of $6 \mathrm{~g} \mathrm{~m}^{-3} \mathrm{~h}^{-1}$ and will decrease to $80 \%$ at the flow rates of $25.5 \mathrm{~g} \mathrm{~m}^{-3} \mathrm{~h}^{-1}$. However, this is not the case in the position of $80 \mathrm{~cm}$ (gas outlet) which shows for three different gas flow rate $\left(30 \mathrm{Lh}^{-1}, 48 \mathrm{Lh}^{-1}\right.$, and $\left.66 \mathrm{Lh}^{-1}\right)$ the $\mathrm{H}_{2} \mathrm{~S}$ removal efficiency achieved almost the same value (about 95\%). The phenomena are conseivable since at $80 \mathrm{~cm}$, the $\mathrm{H}_{2} \mathrm{~S}$ removals are almost complete, so the defferences are not significant.

\subsubsection{Effects of axial distance}

From Table 1 and Fig. 6, it was observed that in the same flow rate and time, $\mathrm{H}_{2} \mathrm{~S}$ removal efficiency will increase with the increasing distance from the bottom of the column. This happens as a larger distance from the bottom of the column will provide a longer contact time between the biogas and the biofilm, making 


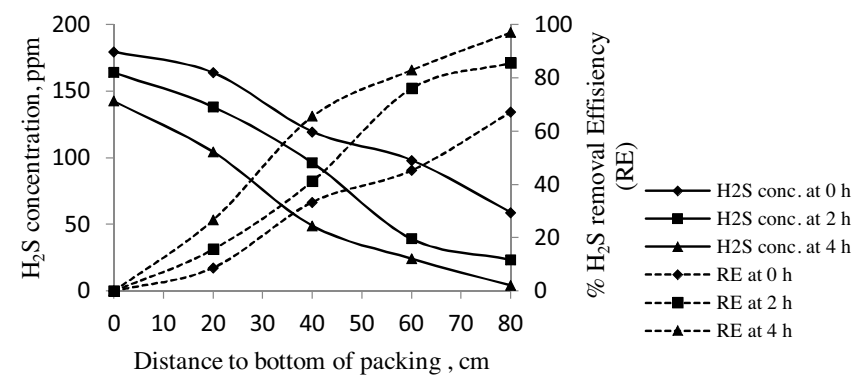

Fig. 5. $\mathrm{H}_{2} \mathrm{~S}$ Concentration and $\mathrm{H}_{2} \mathrm{~S}$ Removal Efficiency at various time of operation at various position in the packed bed.

the removal of $\mathrm{H}_{2} \mathrm{~S}$ more effective. In this packing column $(80 \mathrm{~cm}$ long and $8 \mathrm{~cm}$ inside diameter, thus $\mathrm{L} / \mathrm{D}=10$ ), the highest $\mathrm{H}_{2} \mathrm{~S}$ removal efficiency achieved was $97.15 \%$.

\subsubsection{Packing material}

In this research, SFS was used as packing material. In the gas flow rates of $48 \mathrm{Lh}^{-1} \mathrm{H}_{2} \mathrm{~S}$, at $80 \mathrm{~cm}$ column height removal efficiency could reach $94.35 \%$. Fig. 6 shows that higher $\mathrm{H}_{2} \mathrm{~S}$ removal efficiency can be achieved by using higher column. Rattanapan et al. [7] showed that bacteria growing in granular active carbon granular could eliminate $99 \%$ of $\mathrm{H}_{2} \mathrm{~S}$. Fernández et al. [29] studied a biotrickling filter packed with open polyurethane foam (OPUF) using nitrate-reducing and sulfide-oxidizing bacteria (NR-SOB) as the inoculum and a removal efficiency of $99 \%$ was obtained when working under the following conditions: inlet loads below $130 \mathrm{~g} \mathrm{~s}^{-1} \mathrm{~m}^{-3}$, temperature of $30^{\circ} \mathrm{C}, \mathrm{pH}$ between 7.4 and 7.5 and trickling liquid velocity (TLV) between 5 and 15 . These results suggest that SFS as packing material in a biofilter system is comparable to other packing materials.

\subsection{Modelling}

Simulations applying the mathematical model proposed were performed using adjustable values of parameters involved until the results are close to the experimental data obtained. The comparison between the calculated results and the experimental data is also shown in Figs. 7-10, it can be observed that the calculation results are close to the experimental data. It means that the mathematical model proposed is adequate to quantitatively describe $\mathrm{H}_{2} \mathrm{~S}$ removal from biogas using biofilm on packed bed of SFS.

Those simulations were run using adjustable parameters. It turns out that the appropriate values of the parameters are

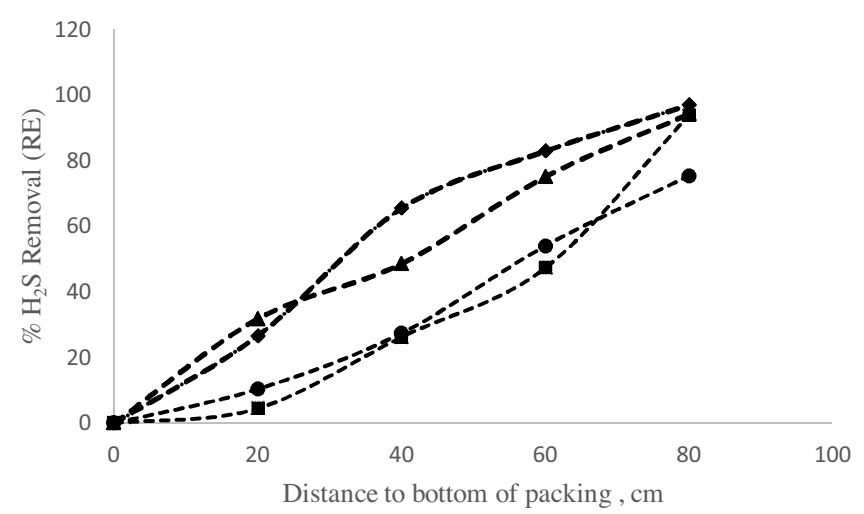

Fig. 6. $\mathrm{H}_{2} \mathrm{~S}$ removal efficiency at various distance from the biogas inlet for different gas flow rate at $4 \mathrm{~h}$ of time operation ( $\bullet=$ flow rate $8550 \mathrm{~g} \mathrm{~m}^{-3} \mathrm{~h}^{-1}, \boldsymbol{\Delta}=$ flow rate $13680 \mathrm{~g} \mathrm{~m}^{-3} \mathrm{~h}^{-1}, \mathbf{\square}=$ flow rate $18810 \mathrm{~g} \mathrm{~m}^{-3} \mathrm{~h}^{-1}, \quad=$ flow rate $23940 \mathrm{~g} \mathrm{~m}^{-3} \mathrm{~h}^{-1}$ ).

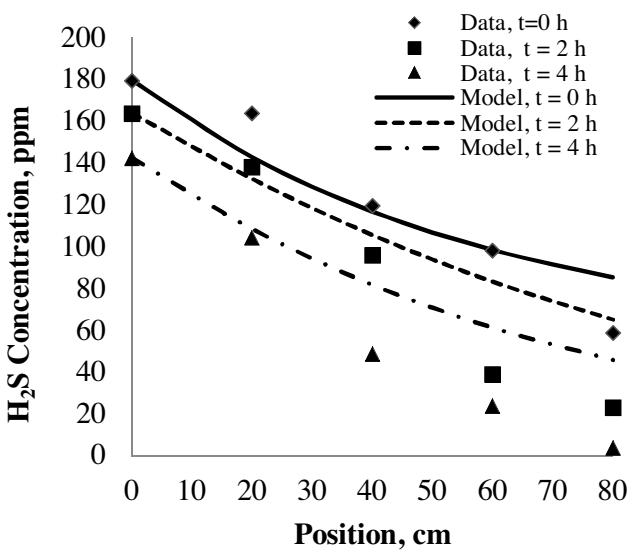

Fig. 7. $\mathrm{H}_{2} \mathrm{~S}$ concentration versus Position at $\mathrm{Q}=8550 \mathrm{~g} \mathrm{~m}^{-3} \mathrm{~h}^{-1}$.

$\mu_{\max }=0.0000007 \mathrm{~s}^{-1}, \mathrm{~K}_{\mathrm{S}}=0.0000039 \mathrm{~g} \mathrm{~cm}^{-3}, \quad \mathrm{k}_{\mathrm{G}}=0.0086 \mathrm{~cm} \mathrm{~s}^{-1}$, $\mathrm{H}_{\mathrm{s}}=0.9$, and $\mathrm{Y}_{\mathrm{x} / \mathrm{s}}=10$. By comparing the calculated results and the experimental data, it can be concluded that the mathematical model proposed can sufficiently describe the performance of the $\mathrm{H}_{2} \mathrm{~S}$ removal. The kinetics modelling in this study was formulated based on 2 major asumptions which were pseudo steady-state process in the gas phase and hydrogen sulfide concentration in the biofilter for a given height is considered to be uniform $\left(\mathrm{H}_{2} \mathrm{~S}\right.$ diffusion in the biofilm is fast). This kinetics modelling is can be improved by removing the 2 major asumption. We are still working to explore this possibility. The results would be compared to the current kinetics modelling results to verify whether or not significant improvement could be achieved.

From the modelling and experimental data it was found that the value of rate of maximum spesific growth $\left(\mu_{\max }\right)=0.0000007$ $\mathrm{s}^{-1}=0.06048 \mathrm{day}^{-1}$. Jiang and Tay, found the value of $3.61 \mathrm{day}^{-1}$ [30], Mora et al., found the value of $0.396 \mathrm{~h}^{-1}=9504 \mathrm{day}^{-1}$ [31], while Xu et al., 2013 found the value of 0.672 day $^{-1}$ [32], Neil et al., 2006 found the value of 0.96 day $^{-1}$ [33], and Heijnen and Kleerebezem found the value of $0.22 \mathrm{~h}^{-1}=5.28$ day $^{-1}$ [34]. This comparison shows that our value is relatively smaller. However the removal efficiency seems to be comparable. This suggests that the biodegradation reaction is not the rate controlling step. There are other factors controlling the rate of overall process, such as mass transfer from the biogas to biofilm. Further investigations are suggested.

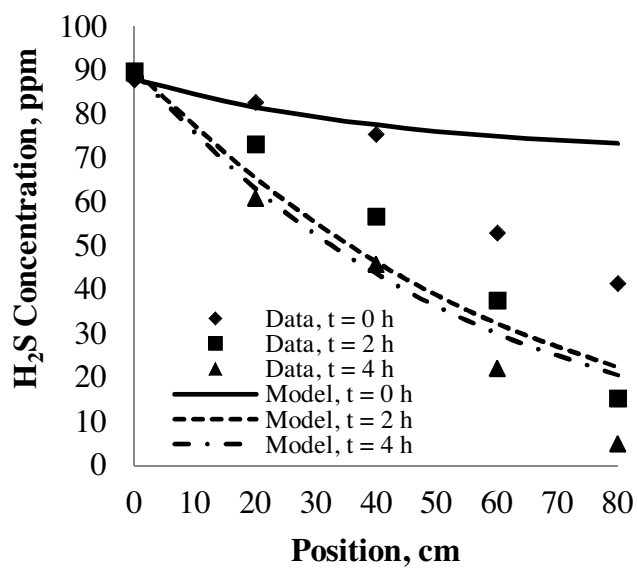

Fig. 8. $\mathrm{H}_{2} \mathrm{~S}$ concentration versus Position at $\mathrm{Q}=13680 \mathrm{~g} \mathrm{~m}^{-3} \mathrm{~h}^{-1}$. 


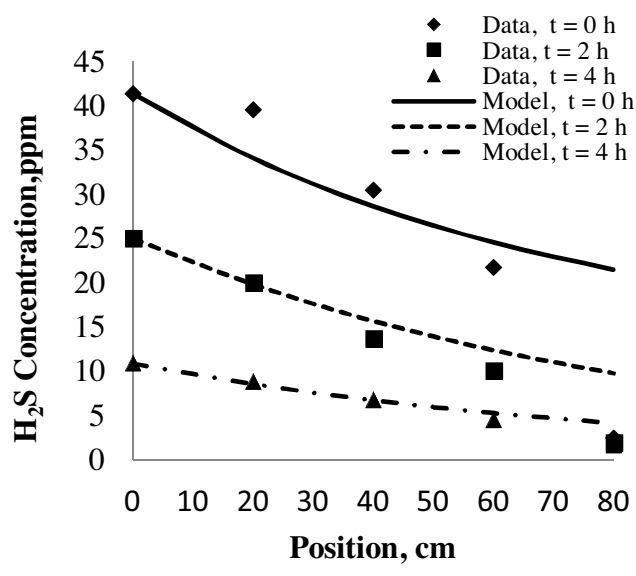

Fig. 9. $\mathrm{H}_{2} \mathrm{~S}$ concentration versus Position at $\mathrm{Q}=18810 \mathrm{~g} \mathrm{~m}^{-3} \mathrm{~h}^{-1}$.

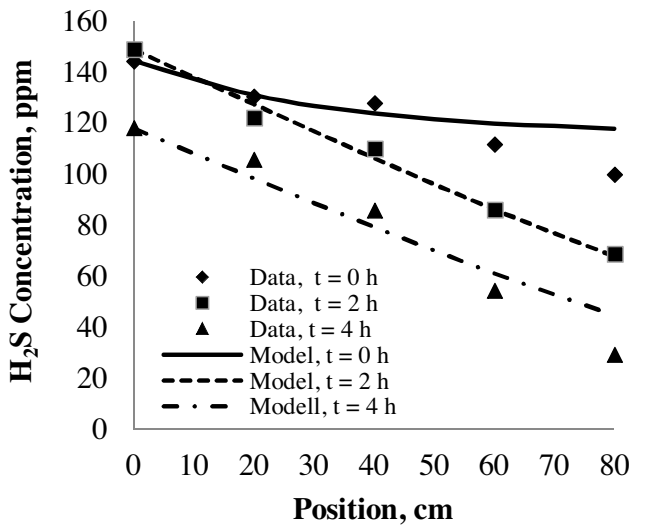

Fig. 10. $\mathrm{H}_{2} \mathrm{~S}$ concentration versus Position at $\mathrm{Q}=23940 \mathrm{~g} \mathrm{~m}^{-3} \mathrm{~h}^{-1}$.

\section{Conclusions}

The main objective of the research is to observe the performance of $\mathrm{H}_{2} \mathrm{~S}$ removal using biofilter attached on salak fruit seeds (SFS). Selected microorganisms from municipal wastewater plant was used as inoculums. Laboratory experiments using biofilm on SFS in a column of $80 \mathrm{~cm}$ height and $8 \mathrm{~cm}$ inside diameter could decrease $\mathrm{H}_{2} \mathrm{~S}$ content in biogas from $142.48 \mathrm{ppm}$ to $4.06 \mathrm{ppm}$ during $4 \mathrm{~h}$ of operation at biogas flow rates of $8550 \mathrm{~g} \mathrm{~m}^{-3} \mathrm{~h}^{-1}$. Thus $97.15 \%$ of $\mathrm{H}_{2} \mathrm{~S}$ could be removed from the biogas. Mathematical models developed can quantitatively describe the process removal of $\mathrm{H}_{2} \mathrm{~S}$ from biogas using a biofilter in a packed bed of salak fruit seeds. The suitable values of the parameters are as follows: $\mu_{\max }=0.0000007\left(\mathrm{~s}^{-1}\right), \mathrm{K}_{\mathrm{S}}=0.0000039\left(\mathrm{~g} \mathrm{~cm}^{-3}\right), \mathrm{k}_{\mathrm{G}}=0.0086(\mathrm{~cm}$ $\left.\mathrm{s}^{-1}\right), \mathrm{H}_{\mathrm{S}}=0.9\left(\left(\mathrm{~g} \mathrm{~cm}^{-3}\right) /\left(\mathrm{g} \mathrm{cm}^{-3}\right)\right)$, and $\mathrm{Y}_{\mathrm{x} / \mathrm{s}}=10$.

\section{Acknowledgements}

The authors would like to acknowledge to Directorate General of Higher Educations of Indonesia, for financial support of the research through scholarship of doctorate program (BPPDN) at Gadjah Mada University and through research grant of Hibah Bersaing 2015 and Sandwich-Like program 2015.

\section{References}

[1] H.R. Amini, D.R. Reinhart, Regional prediction of long-term landfill gas to energy potential, Waste Manage. 31 (2011) 2020-2026.

[2] Yadvika, Santosh, T.R. Sreekrishnan, S. Kohli, V. Rana, Enhancement of biogas production from solid substrates using different techniques-a review, Bioresour. Technol. 95 (2004) 1-10.

[3] M.J. Poloncarzova, V. Vejrazka, P. Vesely, Izak, Effective purification of biogas by a condensing-liquid membrane, Angew. Chem. Int. Ed. 50 (2011) 669-671.

[4] M. Syed, G. Soreanu, P. Falletta, M. Béland, Removal of hydrogen sulfide from gas streams using biological processes-a review, Can. Biosyst. Eng. 48 (2006) $2.1-2.14$.

[5] S.A.M. Marzouk, M.H. Al-Marzouqi, M. Teramoto, N. Abdullatif, Z.M. Ismail, Simultaneous removal of $\mathrm{CO}_{2}$ and $\mathrm{H}_{2} \mathrm{~S}$ from pressurized $\mathrm{CO}_{2}-\mathrm{H}_{2} \mathrm{~S}-\mathrm{CH}_{4}$ gas mixture using hollow fiber membrane contactors, Sep. Purif. Technol. 86 (2012) 88-97.

[6] G. Lastella, C. Testa, G. Cornacchia, M. Notornicola, F. Voltasio, V.K. Sharma, Anaerobic digestion of semi-solid organic waste: biogas production and its purification, Energy Convers. Manage. 43 (1) (2002) 63-75.

[7] C. Rattanapan, P. Boonsawang, D. Kantachote, Removal of $\mathrm{H}_{2} \mathrm{~S}$ in downflow GAC biofiltration using sulfide oxidizing bacteria from concentrated latex waste water, Bioresour. Technol. 100 (2009) 125-130.

[8] S. Pipatmanomai, S. Kaewluan, T. Vitidsant, Economic assessment of biogas to electricity generation system with $\mathrm{H}_{2} \mathrm{~S}$ removal by activated carbon in small pig farm, Appl. Energy 86 (2008) 669-674.

[9] I. Boumnijel, H.B. Amor, H. Chekir, N. Hajji, Hydrogen sulphide removal from the effluents of a phosphoric acid production unit by absorption into chlorinated seawater under alkaline conditions, C. R. Chim. xxx (2016) 1-8.

[10] M. Taheri, A. Mohebbi, H. Hashemipour, A.M. Rashidi, Simultaneous absorption of carbon dioxide $\left(\mathrm{CO}_{2}\right)$ and hydrogen sulfide $\left(\mathrm{H}_{2} \mathrm{~S}\right)$ from $\mathrm{CO}_{2}-\mathrm{H}_{2} \mathrm{~S}-\mathrm{CH}_{4}$ gas mixture using amine-based nanofluids in a wetted wall column, J. Nat. Gas Sci. Eng. 28 (2016) 410-417.

[11] C.C. Lien, J.L. Lin, C.H. Ting, Water scrubbing for removal of hydrogen sulfide $\left(\mathrm{H}_{2} \mathrm{~S}\right)$ inbiogas from Hog farms, J. Agric. Chem. Environ. 3 (2014) 1-6.

[12] M.R. Al Mamun, S. Torii, Removal of hydrogen sulfide $\left(\mathrm{H}_{2} \mathrm{~S}\right)$ from biogas using zero-valent iron, J. Clean Energy Technol. 3 (6) (2015) 428-432.

[13] A. Elias, A. Barona, A. Arreguy, J. Rios, I. Aranguiz, J. Penas, Evaluation of a packing material for the biodegradation of $\mathrm{H}_{2} \mathrm{~S}$ and product analysis, Process Biochem. 37 (2002) 813-820.

[14] M.T. Namini, S.M. Heydarian, B. Bonakdarpour, Removal of $\mathrm{H}_{2} \mathrm{~S}$ from synthetic waste gas streams using a biotrickling filter, Iran. Chem. Eng. J. 5 (3) (2007) 40 51.

[15] J.S. Devinny, M.A. Deshusses, T.S. Webster, Biofiltration for Air Pollution Control, Lewish Publishers, New York, 1999.

[16] M. Hirai, M. Ohtake, M. Shoda, Removal kinetik of hydrogen sulfide, methanotiol and dimethyl sulfide by pear biofilter, J. Ferment. Bioeng. (1990).

[17] M.C. Delhomenie, M. Heitz, Biofiltration of air: a review, Crit. Rev. Biotechnol $25(1-2)$ (2005) 53-72.

[18] M.E. Fischer, Biogas Purification: $\mathrm{H}_{2} \mathrm{~S}$ Removal Using Biofiltration. MASc Thesis, Grad. Dept. of Chemical Engineering, University of Waterloo, Ontario Canada, 2010.

[19] Y.C. Chung, C. Huang, C.P. Tseng, Pan Jr., Microbial oxidation of hydrogen sulfide with biofilter, J. Environ. Sci. Health Part A-Environ Sci. Eng. Toxic Hazard. Subst. Control 31 (6) (1996) 1263-1278.

[20] I.A. Sari, Dinamika awal biofiltrasi untuk pemurnian biogas: perubahan sulfida terlarut dengan bahan isian biji salak (Salacca zalacca), Master Thesis, Chemical Engineering, Gadjah Mada University, Yogyakarta, Indonesia, 2015.

[21] E.Y. Lee, K.S. Cho, H.W. Ryu, Simultaneous removal of $\mathrm{H}_{2} \mathrm{~S}$ and $\mathrm{NH}_{3}$ in biofilte inoculates with Acidithiobacillus thioxidans TAS, J. Biosci. Bioeng. 99 (2005) 2531.

[22] P. Edmonds, Microbiology an Environmental Perspective, Collier Macmillan Publisher, London-New York, 1978.

[23] R.A.S. Lestari, W.B. Sediawan, S. Syamsiah, Sarto, The exploratory study on sulfide removal ability of sulfur-oxidizing bacteria in biofilm on salak fruit seeds, International Proceeding of Chemical, Biological \& Environmental Engineering, Chemical Engineering and ApplicationsV, Taipei, Taiwan, 2014 pp. 16-19.

[24] R.A.S. Lestari, W.B. Sediawan, S. Syamsiah, Sarto, Development of quantitative model for predicting $\mathrm{H}_{2} \mathrm{~S}$ removal fro biogas using microbial film, International Proceeding of 20th Regional Symposium on Chemical Engineering, Bohol, Phillipines, 2013, pp. 131-135.

[25] R.B. Bird, W.E. Steward, E.N. Lightfoot, Transport Phenomena, John Wiley\& Sons, 2007.

[26] J. Monod, The grow of bacterial cultures, Annu. Rev. Microbiol. 3 (1949) 371

[27] A.H. Wani, R.M.R. Branion, A.K. Lau, Effects of periods of starvation and fluctuating hydrogen sulfide concentration on biofilter dynamics and performance, J. Hazard. Mater. 60 (3) (1998) 287-303.

[28] E. Dumont, Y. Andrès, Evaluation of innovative packing materials for the biodegradation of hydrogen sulfide: a comparative study, J. Chem. Technol. Bitechnol. 85 (2010) 429-434.

[29] M. Fernandez, M. Ramirez, J.M. Gomez, D. Cantero, Biogas biodesulfurization in an anoxic biotrickling filter packed with open-pore polyurethane foam, J. Hazard. Mater. 264 (2014) 529-535.

[30] X. Jiang, J.H. Tay, Removal mechanisms of $\mathrm{H}_{2} \mathrm{~S}$ using exhausted carbon in biofiltration, J. Hazard. Mater. 185 (2011) 1543-1549. 
[31] M. Mora, L.R. Lopez, J. Lafuente, J. Perez, R. Kleerebezem, M.C.M. Loosdrecht, X. Gamisans, D. Gabriel, Respirometric characterization of aerobic sulfide, thiosulfate and elemental sulfur oxidation by S-oxidizing biomass, Water Res. 89 (2016) 282-292.

[32] X. Xu, C. Chen, D.J. Lee, A. Wanga, W. Guo, X. Zhou, H. Guo, Y. Yuan, N. Ren, J.S Chang, Sulfate-reduction, sulfide-oxidation and elemental sulfur bioreduction process: modeling and experimental validation, Bioresour. Technol. 147 (2013) 202-211.
[33] C. Neill, J. Gignoux, Soil organic matter decomposition driven by microbial growth: a simple model for a complex network of interactions, Soil Biol. Biochem. 38 (2006) 803-811.

[34] J.J. Heijnen, R. Kleerebezem, Bioenergetics of microbial growth, in: M.C. Flickinger (Ed.), Encyclopedia of Industrial Biotechnology, John Wiley \& Sons Inc., 2009. 